\title{
PENGARUH EKSTRAK DAUN KELADI TIKUS (Typhonium flagelliforme) TERHADAP AKTIVITAS ANTIMUTAGENIK PADA MENCIT (Mus musculus) DENGAN MENGGUNAKAN METODE MIKRONUKLEUS ASSAY
}

\author{
Syafruddin*), Suriani*), Nahdawati*), Sesilia Rante Pakadang**) \\ ${ }^{*}$ Universitas Indonesia Timur Makassar \\ **) Jurusan Farmasi Poltekkes Kemenkes Makassar
}

\author{
Koresponden \\ Sesilia Rante Pakadang \\ Jalan Baji Gau no. 10 Makassar \\ HP. 0811440768 \\ Email : mamajassy@gmail.com
}

\begin{abstract}
ABSTRAK
Penelitian ini bertujuan mengetahui pengaruh ekstrak daun keladi tikus (Typhoniumflagelliforme) terhadap aktivitas antimutagenik pada mencit (Musmusculus) dan menentukan pada konsentrasi berapa ekstrak daun keladi tikus memberikan aktivitas antimutagenik paling baik. Uji antimutagenik dilakukan dengan metode uji mikronukleus (MN) dengan melihat penurunan jumlah mikronukleus pada 200 seleritrositpolikromatik (PCE) sumsum tulang paha mencit yang telah diinduksi larutan siklofosfamid $50 \mathrm{mg} / \mathrm{kgBB}$. Hasil penelitian menunjukkan bahwa pemberian ekstrak etanol daun keladi tikus (Typhoniumflagelliforme) dengan dosis $0,5 \mathrm{mg} / \mathrm{kgBB}$, $1 \mathrm{mg} / \mathrm{kgBB}$, dan $1,5 \mathrm{mg} / \mathrm{kgBB}$ yang diberikan selama 7 hari secara oral mampu menurunkan jumlah persentase seleritrositpolikromatik (PCE) yang bermikronukleus yang diamati melalui preparat apusan sumsum tulang paha mencit. konsentrasi yang paling efektif yaitu pada dosis 1,5 $\mathrm{mg} / \mathrm{kgBB}$ dengan persentase penurunan MNPCE sebesar $92 \%$, , dan rerata peresentasi penurunan mikronukleus sebesar $80 \%$.
\end{abstract}

\section{Kata kunci : Ekstrak daun keladi tikus (Typhoniumflagelliforme), Antimutagenik, Mikronukleus (MN}

\section{PENDAHULUAN}

Kanker sudah luas diakui sebagai salah satu penyakit utama yang membahayakan kesehatan manusia dan di berbagai Negara sudah menjadi agenda masalah kesehatan yang semakin penting. Diperkirakan dalam 25 tahun mendatang di seluruh dunia akan terdapat sekitar 300 juta orang penderita baru kanker, 200 juta orang akan meninggal karena kanker, 2/3 diantara penderita itu terdapat di Negara berkembang (Desen dan Japaries, 2011).

$$
\text { Menurut data GLOBOCAN }
$$

(IARC) Tahun 2012 diketahui bahwa kanker payudara merupakan penyakit kanker dengan kasus baru (setelah dikontrol oleh umur) tertinggi, yaitu sebesar $43,3 \%$, dan persentase kematian (setelah dikontrol oleh umur) akibat kanker payudara sebesar $12,9 \%$. Sedangkan kanker paru tidak hanya merupakan jenis kanker dengan kasus baru tertinggi dan penyebab utama kematian akibat kanker pada penduduk laki-laki, namun kanker paru juga memiliki presentase cukup tinggi pada penduduk perempuan, yaitu sebesar $13,6 \%$ dan kematian akibat kanker paru sebesar $11,1 \%$. Secara nasional prevalensi penyakit kanker pada penduduk semua umur di Indonesia tahun 2013 sebesar 1,4\% atau diperkirakan sekitar 347.792 orang. Penyakit kanker serviks dan payudara merupakan penyakit kanker dengan prevalensi tertinggi di Indonesia pada tahun 2013, yaitu kanker serviks sebesar 0,8\% dan kanker payudara sebesar $0,5 \%$ (Kemenkes RI, 2015).

Kanker yang paling banyak menimbulkan korban adalah kanker paruparu, usus besar (kolorektal), payudara, prostat, dan perut. Hampir setengah dari 
seluruh jumlah kematian akibat kanker disebabkan kanker jenis ini. Ditambah kanker kulit, kanker-kanker ini merupakan jenis kanker yang paling umum menyerang manusia (Haryanto N, 2009).

Secara umum, senyawa karsinogen dapat diartikan sebagai zat penyebab kanker. Senyawa ini mempunyai efek fisiologis yang sama dengan senyawa beracun lain. Senyawa karsinogen pada permulaannya dapat dibedakan menjadi tiga golongan, yaitu poliinti hidrokarbon aromatik, amina aromatik, dan zat warna azo (Andriyanto T, 2011).

Organisasi penelitian kanker internasional (IARC) berdasarkan standar karsinogen manusia telah mengemukakan 42 jenis zat kimia karsinogenik terhadap manusia yang terdapat dalam lingkungan hidup kita. Di dalam lingkungan faktor karsinogenik meliputi faktor fisika, kimia, dan biologis dan yang tersebar paling luas adalah karsinogen faktor kimia (Desen dan Japaries, 2011).

Pada dasarnya mayoritas bahan kimia yang bersifat karsinogenik memiliki sifat yang sama, yaitu memicu terjadinya suatu mutasi gen. Mutagen (mutagene) adalah suatu bahan yang dapat menginduksi DNA menjadi mutasi. Adapun yang dimaksud dengan mutasi (mutation) adalah perubahan susunan nukleotida pada DNA baik karena pengurangan, penambahan maupun perpindahan atau pertukaran (Sudiana I K, 2011).

Metode pengobatan kanker yang banyak digunakan saat ini adalah metode kemoterapi, radiasi, dan operasi. Metodemetode tersebut bertujuan untuk mengangkat jaringan sel kanker atau untuk mematikan sel kanker. Akan tetapi metodemetode tersebut belum maksimal, bahkan memberikan efek samping pada sel normal yang berada disekitar sel kanker atau organ lain (Multiawati N, 2013).

Untuk menghindarinya, orang mulai beralih pada obat-obatan herbal. Peran utama obat herbal dalam penyembuhan kanker yaitu meningkatkan daya tahan tubuh pasien dan melokalisasi sel-sel kanker. Selsel kanker akhirnya menjadi tidak mudah menyebar dan lebih mudah diangkat (dioperasi). Obat herbal diketahui lebih aman bagi tubuh pasien (Andriyanto T, 2011).

Salah satu tanaman obat yang digunakan untuk pengobatan kanker adalah tanaman keladi tikus (Typhonium flagelliforme) famili araceae dan merupakan salah satu jenis tanaman liar yang belum banyak dikenal oleh masyarakat. Secara empiris, masyarakat Indonesia menggunakan tanaman tersebut untuk mengobati penyakit kanker atau tumor (Farida Y, et al., 2010).

Orang banyak mengenal keladi sebagai umbi talas yang biasa menjadi salah satu bahan untuk makanan. Namun, keladi tikus berbeda lagi dari yang biasa. Keladi tikus lebih banyak dijadikan bahan untuk obat tradisional. Keladi tikus (Typhonium flagelliforme) mulai banyak dan semakin dikenal sebagai bahan untuk obat pembasmi kanker payudara. Bagian yang digunakan adalah seluruh tanamannya baik daun, hingga ke umbinya. Beberapa penyakit biasa diatasi dengan pengobatan luar dengan keladi tikus. Contohnya saja, pertolongan pertama untuk gigitan lipan atau ular, radang kulit (pyoderma), bisul (furunculus), tumor yang berasal dari pembuluh darah (hemangioma), luka, borok, koreng dan patek (frambusia) (Maysaroh H, 2013).

Kandungan tanaman keladi tikus yang memiliki efek antikanker adalah triterpenoid, alkaloid, polifenol, Ribosome Inactivating protein (RIP), dan fitol (Medawati A, et al., 2012).

Pada penelitian sebelumnya yang dilakukan oleh (Iswantini,et al., 2009) menunjukkan bahwa ekstrak air dan etanol keladi tikus (Typhonium flagelliforme) berpotensi sebagai antikanker.

Berdasarkan latar belakang diatas, maka timbul permasalahan yaitu apakah ekstrak daun keladi tikus (Typhonium flagelliforme) berpengaruh terhadap aktivitas antimutagenik pada mencit (Mus musculus) dan pada konsentrasi berapa yang paling efektif?

Adapun tujuan penelitian ini yaitu untuk mengetahui pengaruh ekstrak daun keladi tikus (Typhonium flagelliforme) terhadap aktivitas antimutagenik pada mencit (Mus musculus) dan menentukan pada konsentrasi berapa ekstrak daun keladi 
tikus memberikan aktivitas antimutagenik paling baik.

Adapun manfaat dari penelitian ini adalah untuk memperoleh data ilmiah dan dapat menambah informasi tentang tanaman keladi tikus (Typhonium flagelliforme) sebagai salah satu obat yang mempunyai aktivitas antimutagenik secara alami, dan juga sebagai acuan untuk penelitian lebih lanjut mengenai pemanfaaatan ekstrak daun keladi tikus di bidang kesehatan.

\section{METODE DAN BAHAN}

Lokasi Dan Rancangan Penelitian

Penelitian ini dilakukan pada bulan Oktober 2017 di Laboratorium Instrumen dan Farmakologi Klinik Fakultas Farmasi Universitas Muslim Indonesia Makassar

\section{Alat dan Bahan}

Alat-alat yang digunakan dalam penelitian ini meliputi batang pengaduk, blender (National), botol kaca kecil (vial), deck glass, gelas kimia (Pyrex $\left.{ }^{\circledR}\right)$, gelas piala (Pyrex $\left.{ }^{\circledR}\right)$, gelas untuk pewarna, gunting bedah, kanula (sonde), labu ukur (Pyrex $\left.{ }^{\circledR}\right)$, mikroskop (Olympus®), mikrotube, objek glass, Optic lab mikroskop connecter, pentul, pinset, pipet tetes, pisau bedah, seperangkat alat maserasi, sendok tanduk, sentrifuge, spoit $1 \mathrm{~mL}$, spoit $20 \mathrm{~mL}$, stirrer, stopwatch, timbangan analitik ohaus (Camry®), dan timbangan hewan uji. Bahan-bahan yang digunakan yaitu air suling, aluminium foil, dapar fosfat, ekstrak daun keladi tikus (Typhonium flagelliforme), entelan, etanol 96\%, gabus, kain kasa, methanol, minyak emersi, Natrium Karboksil Metil Selulosa (Na CMC) (teknis), $\mathrm{NaCl} 0,9 \%$, pewarna giemsa, pewarna May-Gruenwald, Siklofosfamid (Kalbe Farma), serum darah sapi segar (serum bovine albumin) (Erybank®), dan xilol.

\section{Cara Kerja}

1. Pengambilan Sampel

$$
\text { Bahan penelitian yang }
$$
digunakan adalah daun keladi tikus (Typhonium flagelliforme) yang diambil dari kabupaten Sinjai, Sulawesi Selatan.
2. Pengolahan Sampel

Daun keladi tikus yang telah dikumpulkan, dilakukan pencucian, lalu ditiriskan dan ditimbang. Kemudian dipotong-potong kecil, setelah itu dikeringkan dengan cara di anginanginkan, lalu dilakukan ekstraksi dengan cairan penyari etanol $96 \%$.

3. Ekstraksi Sampel dengan metode Maserasi

Simplisia daun keladi tikus ditimbang sebanyak 1000 gram. Lalu dimasukkan ke dalam bejana maserasi dan ditambahkan etanol $96 \%$ hingga terendam sempurna. Bejana ditutup rapat lalu didiamkan selama 5 hari dan sesekali di aduk. Setelah lima hari disaring lalu cairan penyari di ganti dengan pelarut yang baru dan dimaserasi kembali hingga simplisia tersari sempurna. Ekstrak yang di peroleh di kumpulkan kemudian di uapkan dengan menggunakan rotavapor untuk mendapatkan ekstrak kental. Setelah itu di uapkan di atas penangas air untuk mendapatkan ekstrak kering.

4. Pembuatan suspensi Na. CMC 1\%

Ditimbang 1 gram Na.CMC, dimasukkan kedalam $50 \mathrm{~mL}$ aquadest yang telah dipanaskan sedikit demi sedikit, lalu di aduk hingga terdispersi.Setelah itu, dicukupkan volumenya hingga $100 \mathrm{~mL}$ dan di masukkan kedalam botol.

5. Pembuatan suspensi ekstrak daun keladi tikus

Ekstrak kering daun keladi tikus dengan konsentrasi yaitu 0,0005 $\%$, 0,0010\%, dan $0,0015 \%$ dengan cara ditimbang sebanyak 0,0005 gram disuspensikan dengan air suling steril hingga $100 \mathrm{~mL}$ didapatkan konsentrasi ekstrak 0,0005 \% b/v, pembuatan ekstrak dengan konsentrasi 0,0010\% $\mathrm{b} / \mathrm{v}$ dan $0,0015 \% \mathrm{~b} / \mathrm{v}$ digunakan cara yang sama dimana ekstrak daun keladi tikus ditimbang masing-masing 0,0010 gram, dan 0,0015 gram.

6. Pembuatan suspensi Siklofosfamid $0,02 \% \mathrm{~b} / \mathrm{v}$ sebanyak $100 \mathrm{~mL}$

Suspensi siklofosfamid dibuat dengan menggerus tablet siklofosfamid yang ditimbang setara $20 \mathrm{mg}$ 
siklofosfamid. Kemudian disuspensikan dengan Na.CMC 1\% hingga $100 \mathrm{ml}$. Diaduk hingga homogen kemudian dimasukkan kedalam wadah dan di beri etiket.

7. Penyiapan Hewan Uji

Hewan yang digunakan adalah mencit dengan berat 20-30 g dibagi 5 kelompok dimana setiap kelompok terdiri dari 3 ekor mencit.

8. Perlakuan Hewan Uji Mencit diadaptasi dengan lingkungan penelitian selama 2 minggu. Satu jam sebelum penelitian dipuasakan, selanjutnya dikelompokkan menjadi 5 kelompok, terdiri dari 3 kelompok dosis dan 2 kelompok kontrol. Kelompok I : Kontrol negatif, kelompok mencit yang diberikan larutan suspensi Na.CMC 1\% (1 mL/30 gBB) selama 7 hari secara oral. Kelompok II : Kontrol positif, kelompok mencit yang diinduksikan larutan siklofosfamid dengan dosis $50 \mathrm{mg} / \mathrm{kgBB}$ (i.p) pada hari pertama, kemudian setelah 30 jam diberikan larutan suspensi Na.CMC $1 \%$ (vol. $1 \mathrm{~mL} / 30 \mathrm{gBB}$ ) secara oral setiap hari hingga hari ke 7. Kelompok III : Kelompok mencit yang diinduksikan larutan siklofosfamid dengan dosis 50 $\mathrm{mg} / \mathrm{kgBB}$ pada hari pertama. Setelah 30 jam, diberikan larutan suspensi ekstrak daun keladi tikus (Typhonium flagelliforme) dengan dosis 0,5 $\mathrm{mg} / \mathrm{kgBB}(1 \mathrm{~mL} / 30 \mathrm{gBB})$ secara peroral setiap hari hingga hari ke-7. Kelompok IV : Kelompok mencit yang diinduksikan larutan siklofosfamid dengan dosis $50 \mathrm{mg} / \mathrm{kgBB}$ pada hari pertama. Setelah 30 jam, diberikan larutan suspensi ekstrak daun keladi tikus (Typhonium flagelliforme) dengan dosis $1 \mathrm{mg} / \mathrm{kgBB}(1 \mathrm{~mL} / 30 \mathrm{gBB})$ secara peroral setiap hari hingga hari ke-7. Kelompok V : Kelompok mencit yang diinduksikan larutan siklofosfamid dengan dosis $50 \mathrm{mg} / \mathrm{kgBB}$ pada hari pertama. Setelah 30 jam, diberikan larutan suspensi ekstrak daun keladi tikus (Typhonium flagelliforme) dengan dosis $1,5 \mathrm{mg} / \mathrm{kgBB} \quad(1 \mathrm{~mL} / 30 \mathrm{gBB})$ secara peroral setiap hari hingga hari ke-7.
Pada hari ke-8, hewan dibunuh dengan cara dislokasi leher kemudian dibedah dan tulang femurnya diambil dan dibersihkan ujung proksimal tulang dipotong dan diambil sumsum tulang femurnya menggunakan spoit yang berisi serum bovine sebanyak $0,1 \mathrm{ml}$ dengan dapar fosfat $(1: 1 \mathrm{v} / \mathrm{v})$ dengan cara jarum suntik dimasukkan ke dalam saluran sumsum tulang terbuka lalu cairan sumsum disedot perlahan, syringe kemudian disemprotkan agar cairan sumsum bercampur dengan serum bovine dan dapar fosfat lalu ditampung di dalam mikrotube.

Pembuatan preparat apusan sumsum tulang femur yaitu campuran sumsum tulang dan serum bovine-dapar fosfat $(1: 1 \mathrm{v} / \mathrm{v})$ dalam mikrotube disentrifuge dengan kecepatan 2000 rpm selama 5 menit, kemudian supernatannya dibuang. Endapannya disuspensikan kembali dengan 2 tetes serum bovine-dapar fosfat $(1: 1 \mathrm{v} / \mathrm{v})$. Kemudian satu tetes suspensi sel diambil dan diletakkan di atas slide dan dengan menggunakan slide yang lain ditarik berlawanan arah membentuk sudut $45^{0}$ sehingga terbentuk lapisan yang tipis. Kemudian slide dikering anginkan, difiksasi dengan methanol selama 3 menit. Preparat kemudian dimasukkan ke dalam gelas yang telah diisi pewarna May-Gruenwald. Pewarnaan tersebut dilakukan selama 3 menit. Selanjutnya preparat direndam kembali ke dalam pewarna MayGruenwald yang telah diencerkan dengan aquadest dengan perbandingan 1:1 selama 2 menit, preparat kemudian dicuci dengan aquadest sebanyak 2 kali. Tahap selanjutnya preparat direndam ke dalam gelas yang sudah diisi dengan larutan pewarna giemsa yang telah dicampur dengan dapar fosfat dengan perbandingan 1:23 selama 10 menit. Preparat dicuci dengan aquadest kemudian dikering anginkan. Selanjutnya preparat dicelupkan ke dalam gelas yang diisi larutan xilol selama 10 menit kemudian dibilas dengan aquadest. Dikeringkan, diberi entelan lalu ditutup dengan deg glass 
dan diamati dibawah mikroskop dengan perbesaran 100x10 dengan bantuan minyak emersi. Jumlah sel mikronukleus dalam sel dihitung

\section{Pengolahan Data}

Data dianalisis dengan menggunakan program SPSS 24. Untuk mengetahui adanya perbedaan aktivitas antimutagenik pada tiap perlakuan dilakukan uji ANOVA satu arah.Jika terdapat perbedaan, dilanjutkan dengan menggunakan Uji Least Significancy Density (LSD).

\section{HASIL DAN PEMBAHASAN}

Hasil Penelitian

Berdasarkan penelitian yang telah dilakukan dengan menguji antimutagenik ekstrak daun keladi tikus (Typhonium flagelliforme) pada sel eritrosit sumsum tulang femur mencit dengan menggunakan uji mikronukleus assay, didapatkan hasil sebagai berikut:

Tabel 1. Rerata Jumlah Mikronukleus Per 200 PCE pada sumsum tulang femur mencit selama 7 hari perlakuan :

\begin{tabular}{|c|c|c|c|c|c|}
\hline Perlakuan & $\mathrm{N}$ & $\begin{array}{l}\text { Jumlah } \\
\text { MNPCE }\end{array}$ & Total & $\begin{array}{l}\text { Rerata jumlah } \\
\text { MNPCE } \\
\text { Deviasi Standar }\end{array}$ & $\begin{array}{l}\text { Penurunan } \\
\text { jumlah MNPCE } \\
(\%)\end{array}$ \\
\hline $\begin{array}{c}\text { Klp I } \\
\text { Na.CMC } \\
1 \%\end{array}$ & $\begin{array}{l}2 \\
3 \\
\end{array}$ & $\begin{array}{l}0 \\
0 \\
0\end{array}$ & 0 & $0 \pm 0$ & $100 \%$ \\
\hline $\begin{array}{c}\text { Klp II } \\
\text { Siklofosfamid } 50 \\
\mathrm{mg} / \mathrm{kgBB}\end{array}$ & $\begin{array}{l}2 \\
3\end{array}$ & $\begin{array}{l}147 \\
151 \\
160 \\
\end{array}$ & 458 & $152,67 \pm 6,66$ & $0 \%$ \\
\hline $\begin{array}{c}\text { Klp III } \\
\text { Ekstrak } 0,0005 \%\end{array}$ & $\begin{array}{l}1 \\
2 \\
3\end{array}$ & $\begin{array}{l}75 \\
72 \\
70 \\
\end{array}$ & 217 & $72,33 \pm 2,52$ & $63,83 \%$ \\
\hline $\begin{array}{c}\text { Klp IV } \\
\text { Ekstrak } 0,0010 \%\end{array}$ & $\begin{array}{l}1 \\
2 \\
3\end{array}$ & $\begin{array}{l}32 \\
30 \\
29\end{array}$ & 91 & $30,33 \pm 1,53$ & $84,83 \%$ \\
\hline $\begin{array}{c}\text { Klp V } \\
\text { Ekstrak 0,0015\% }\end{array}$ & $\begin{array}{l}1 \\
2 \\
3 \\
\end{array}$ & $\begin{array}{l}18 \\
16 \\
14 \\
\end{array}$ & 48 & $16 \pm 2$ & $92 \%$ \\
\hline
\end{tabular}

Sumber data : Laboratorium Farmakologi farmasi UMI Makassar

Keterangan :

Kelompok I = Kontrol negatif dengan pemberian larutan NaCMC $1 \% \mathrm{~b} / \mathrm{v}$

Kelompok II = Kontrol positif dengan pemberian larutan Siklofosfamid $50 \mathrm{mg} / \mathrm{KgBB}+\mathrm{NaCMC}$ $1 \% \mathrm{~b} / \mathrm{v}$

Kelompok III = Pemberian Siklofosfamid 50 mg/KgBB + Ekstrak Etanol Daun Keladi Tikus 0,5 $\mathrm{mg} / \mathrm{KgBB}$

Kelompok IV = Pemberian Siklofosfamid $50 \mathrm{mg} / \mathrm{KgBB}+$ Ekstrak Etanol Daun Keladi Tikus 1 $\mathrm{mg} / \mathrm{KgBB}$

Kelompok V = Pemberian Siklofosfamid 50 mg/KgBB + EKstrak Etanol Daun Keladi Tikus 1,5 $\mathrm{mg} / \mathrm{KgBB}$ 


\section{Pembahasan}

Mutasi adalah perubahan pada materi genetik suatu makhluk hidup yang terjadi secara tiba-tiba, acak dan merupakan dasar bagi sumber variasi organisme hidup yang bersifat terwariskan (Chaidar Warianto, 2011:1).

Salah satu indikator terjadinya mutasi adalah mikronukleus (MN). Mikronukleus merupakan hasil mutasi dari kromosom utuh yang patah dan kemudian tampak sebagai nukleus berukuran kecil di dalam suatu sel (Schmid W, 1976:31).

Selain karena patahan kromosom mikronukleus juga dapat terbentuk apabila ada gangguan pada pembentukan benang spindel, yang dapat terjadi apabila sel terpapar pada racun spindel, contohnya kolkisin. Dalam hal ini mikronukleus terbentuk mengandung kromosom yang utuh, bukan sekedar patahan kromosom (Iskandar O, 1981:5).

Pengamatan mikronukleus dilakukan pada sel polikromatik eritrosit (PCE) karena mikronukleus yang terbentuk akibat induksi mutagen dapat terlihat jelas pada sel PCE. Sel PCE juga digunakan dalam pengamatan mikroskopis karena memiliki ukuran yang lebih besar daripada sel normokromatik (NCE) sehingga memudahkan dalam perhitungan. Sel normoblas yang terpajan oleh klastogen akan mengeluarkan nukleusnya (enukleasi) tanpa disertai pengeluaran mikronukleus. Peristiwa enukleasi tersebut terjadi pada tahap PCE dengan mikronukleus yang tetap berada di dalam sitoplasma sel (Heddle dkk. 1983: 65\&74; Cicchetti dkk: 240).

Hasil penelitian pada tabel 1 menunjukkan bahwa rerata jumlah mikronukleus tertinggi terdapat pada kontrol positif sebesar 152,67 lalu berturut-turut Klp I, Klp II, dan Klp III. Hal tersebut sesuai dengan literatur yang menyebutkan bahwa siklofosfamid termasuk karsinogen golongan satu dalam menyebabkan kanker tidak hanya pada manusia tapi juga pada hewan uji.

Siklofosfamid merupakan senyawa antikanker golongan agen pengalkilasi dari golongan nitrogen mustard. Sama seperti agen pengalkilasi lainnya, siklofosfamid memberikan aksi sitotoksika dengan cara mengalkilasi basa nitrogen dalam DNA manusia (Smith dan Clark, 2011).

Siklofosfamid menginduksi metabolit aktifnya yang bersifat pengalkilasi, yaitu fosfamid mustard, akrolein dan 4-hidroksisiklofosfamid. Senyawa pengalkilasi tersebut dapat berikatan dengan berbagai unsur, termasuk berikatan dengan basa DNA. Alkilasi fosfamid mustard pada DNA terjadi pada posisi N7 guanin, N1 dan N3 adenin, N3 sitosin, dan O6 guanin, serta atom-atom fosfat dan protein yang terkait dengan DNA (Katzung, 2004:305). Akibat dari reaksi tersebut antara lain dapat mengakibatkan terjadinya patahan kromosom dan terlihat sebagai mikronukleus (Didi J.P. et al., 2000:20).

Sifat mutagenesis dan karsinogenitas siklofosfamid tersebut muncul sebagai akibat dari alkilasi posisi tertentu pada basa nitrogen, khususnya posisi yang terlibat dalam ikatan hydrogen pada waktu penyusunan kelengkapan pasangan basa komplemen pada proses replikasi DNA yang mengakibatkan terjadinya mutasi titik (mutagenesis) yang jika terakumulasi akan menyebabkan kanker (karsinogenesis) (Rahmawati dan Tabran, 2015).

Tabel hasil penelitian memperlihatkan pada KK- memiliki rerata jumlah mikronukleus sebesar 0 , hal ini menunjukkan pada Na.CMC tidak bersifat mutagenik karena tidak terdapat sel mikronukleus.

Hasil perhitungan uji mikronukleus menunjukkan bahwa persentase penurunan jumlah mikronukleus per 200 sel PCE yang dibandingkan dengan kontrol positif pada Klp I, Klp II dan Klp III secara berurutan yaitu $63,83 \%, 84,83 \%$ dan $92 \%$, sehingga diperoleh rerata presentase penurunan MNPCE yaitu sebesar $80 \%$. Hasil tersebut menunjukkan bahwa peningkatan dosis ekstrak etanol daun keladi tikus berbanding lurus dengan penurunan jumlah mikronukleus. Dengan demikian untuk menentukan mana kelompok perlakuan yang terbaik tentu kelompok perlakuan yang mendekati dengan kontrol negatif dalam hal ini konsentrasi $0,0015 \%$. 
Berdasarkan Uji Liniear RAL dan Analisis Ragam (ANOVA) satu arah diperoleh nilai fh sebesar 870,846 lebih besar daripada ft tabel 3,48 - 5,99 atau $\mathrm{fh}>\mathrm{ft}$ yang menunjukkan adanya perbedaan dalam kelima kelompok perlakuan. Selain itu terlihat adanya penurunan jumlah mikronukleus pada kelompok perlakuan (Klp I, Klp II dan Klp III) dibandingkan kelompok positif. Dengan demikian pemberian ekstrak etanol daun keladi tikus dengan dosis $0,5 \mathrm{mg} / \mathrm{kgBB}, 1 \mathrm{mg} / \mathrm{kgBB}$ dan $1,5 \mathrm{mg} / \mathrm{kgBB}$ mampu menurunkan jumlah mikronukleus.

Berdasarkan hasil uji LSD diketahui bahwa terdapat perbedaan yang signifikan antara kontrol positif dengan semua kelompok eksperimen lainnya (kontrol negatif; Klp I; Klp II; Klp III). Hal tersebut menunjukkan bahwa pemberian ekstrak etanol daun keladi tikus dengan berbagai dosis mampu menurunkan jumlah mikronukleus.

Hal ini sejalan dengan penelitian sebelumnya yang menggunakan tanaman keladi tikus dengan metode yang berbeda, menunjukkan bahwa keladi tikus berpotensi sebagai obat antikanker (Iswantini, et al., 2009). kemampuan tanaman keladi tikus dalam menurunkan jumlah mikronukleus yang menjadi parameter penyebab kanker diduga berasal dari kandungan senyawa yang dimilikinya yaitu triterpenoid yang bekerja dengan menghambat kerja enzim yang berperan dalam proses replikasi dan proliferasi sel kanker. Terhentinya kerja enzim menyebabkan proses dalam sel terhenti dan menyebabkan kematian sel kanker (Mun'im dan Hanani, 2011).

\section{PENUTUP}

Berdasarkan hasil penelitian dan pembahasan maka dapat disimpulkan bahwa ekstrak daun keladi tikus (Typhonium flagelliforme) berpengaruh terhadap aktivitas antimutagenik pada mencit (Mus musculus) berdasarkan penurunan jumlah mikronukleus dan konsentrasi yang memiliki aktivitas antimutagenik paling baik yaitu konsentrasi $0,0015 \%$. Adapun hasil analisis menunjukkan bahwa terdapat perbedaan nyata pada tiap pasangan kelompok data (signifikan) dengan nilai $\mathrm{p}<0,05$.

\section{DAFTAR PUSTAKA}

Andriyanto, T. 2011. Ampuhnya Terapi Herbal Berantas Berbagai Penyakit Berat. Najah: Jogjakarta.

Busk, L., Sjostrom, B., Ahlborg, U.G. (1984). Effect of Vitamin A on Cyclophosphamida Mutagenecity In Vitro (Ames Test) and in vivo (Mouse Micronucleus Test), Fd Chem, Toxic, 22.

Darmono. 2012. Toksikologi Genetik. UIPress: Jakarta.

Desen dan Japaries. 2011. Buku Ajar Onkologi Klinis Edisi 2. Fakultas Kedokteran Universitas Indonesia: Jakarta.

Didi J P, et al,. 2000. Aktivitas Antimutagenik dan Antioksidan Daun Puspa (Schima wallichii kort). Cermin Dunia Kedokteran no. 127.

Farida Y, et al. 2010. Uji Aktivitas Sitotoksik dan Antioksidan Dari Ekstrak Daun Keladi Tikus (Typhonium divaricatum (L) Decne). Fakultas Farmasi Universitas Pancasila: Jakarta.

Gunawan, S. 2011. Farmakologi dan Terapi. Fakultas Kedokteran Universitas Indonesia: Jakarta.

Haryanto, N. 2009. Mengenal, Mencegah, Mengatasi Silent Kanker. Pustaka Widyamara: Semarang.

Iskandar O. 1981. The micronucleus test (method and its Application in Detection Chromosomal abberrations in Human Cells in Culture as well as Diagnosis of Patients with Chromosome Breakage Disrases). Disertasi. Jakarta: University of Indonesia.

Katzung, B G. 2015. Farmakologi Dasar dan Klinik. EGC;Jakarta. 
Kementrian Kesehatan RI. 2015. Cegah Kanker dengan menerapkan perilaku CERDIK. Pusat Data Informasi: Jakarta.

Malole, M.B.M dan Pramono, S.U. 1989. Penggunaan Hewan-hewan Percobaan Di labotarorium. Institut pertanian Bogor: Jakarta.

Maysaroh, H. 2013. Kanker Pada Perempuan dan Penyembuhannya. Trimedia Pustaka: Klaten.

Medawati A, et al. 2012. Potensi Ekstrak Etanol Daun Keladi Tikus (Typhonium flagellifome Lodd.) Sebagai Induktor Apoptosis Sel Kanker Lidah Manusia(SP-C1). PSPDG FKIK UMY.

Mun'im, A dan Hanani, E. 2011. Fito Terapi Dasar. Dian Rakyat: Jakarta.
Rahmawati dan Tabran. 2015 . Uji Aktivitas Antimutagenik Ekstrak Etanol Daun Kemangi (Ocimum basilicum L.) Terhadap mencit Dengan Menggunakan Metode Mikronukleus Assay. Fakultas Farmasi Universitas Indonesia Timur: Makassar.

Schmid W. 1976. The micronucleus test for cytogenetic analysis. Dalam: Hollaende, A. (ed.). 1976. Chemical mutagen : Principles and methods for their detection. 4:31-52.

Smith, F. T dan Clark, C.R. 2012. Antineoplastic Agents. Dalam J. M. Beale dan J. H. Block (Penyunt), Wilson and Gisvold's Textbook of Organic Medical and Pharmaceutial Chemistry (12 th Edition ed., hal. 358-369). Philadelphia: 


\section{Histogram Hasil Penelitian}

Gambar 1. Histogram rerata penurunan jumlah MNPCE pada sumsum tulang femur mencit

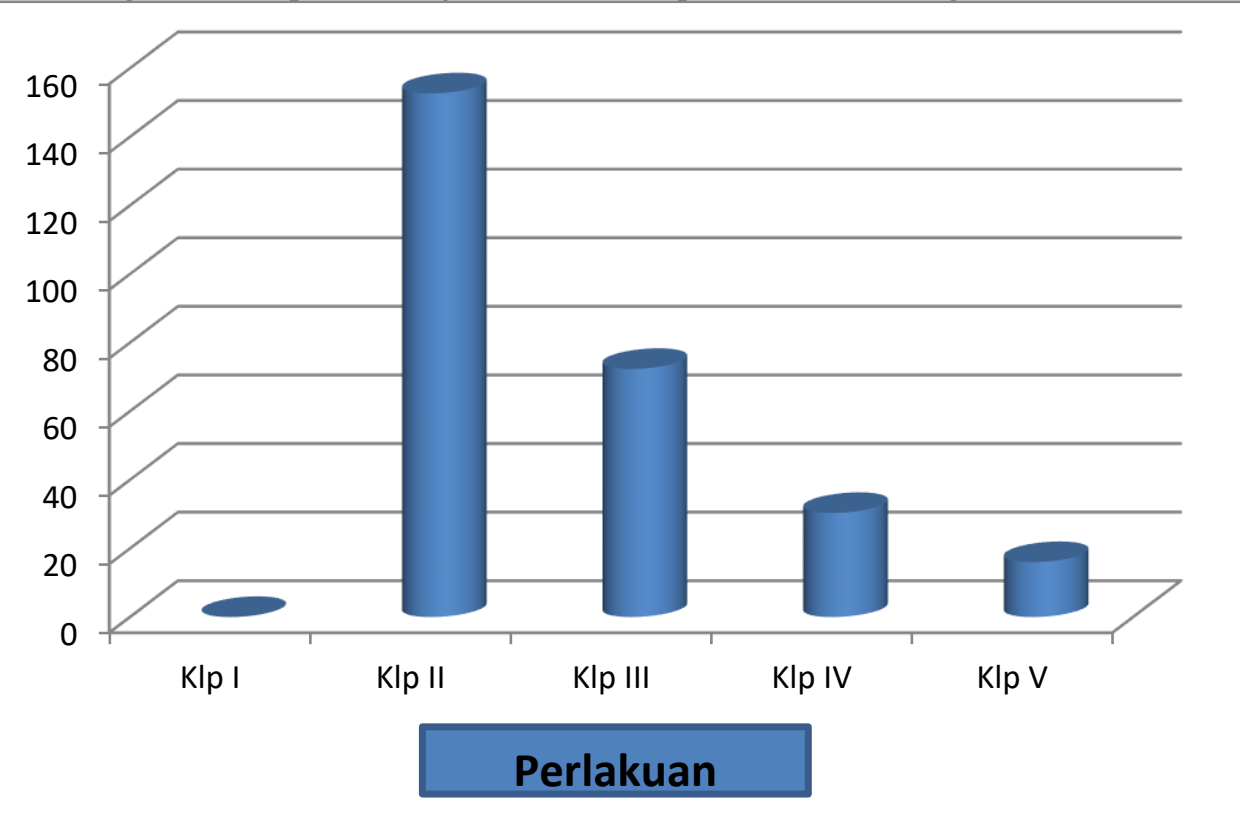

Gambar 2. Histogram persentase penurunan MNPCE pada sumsum tulang femur mencit

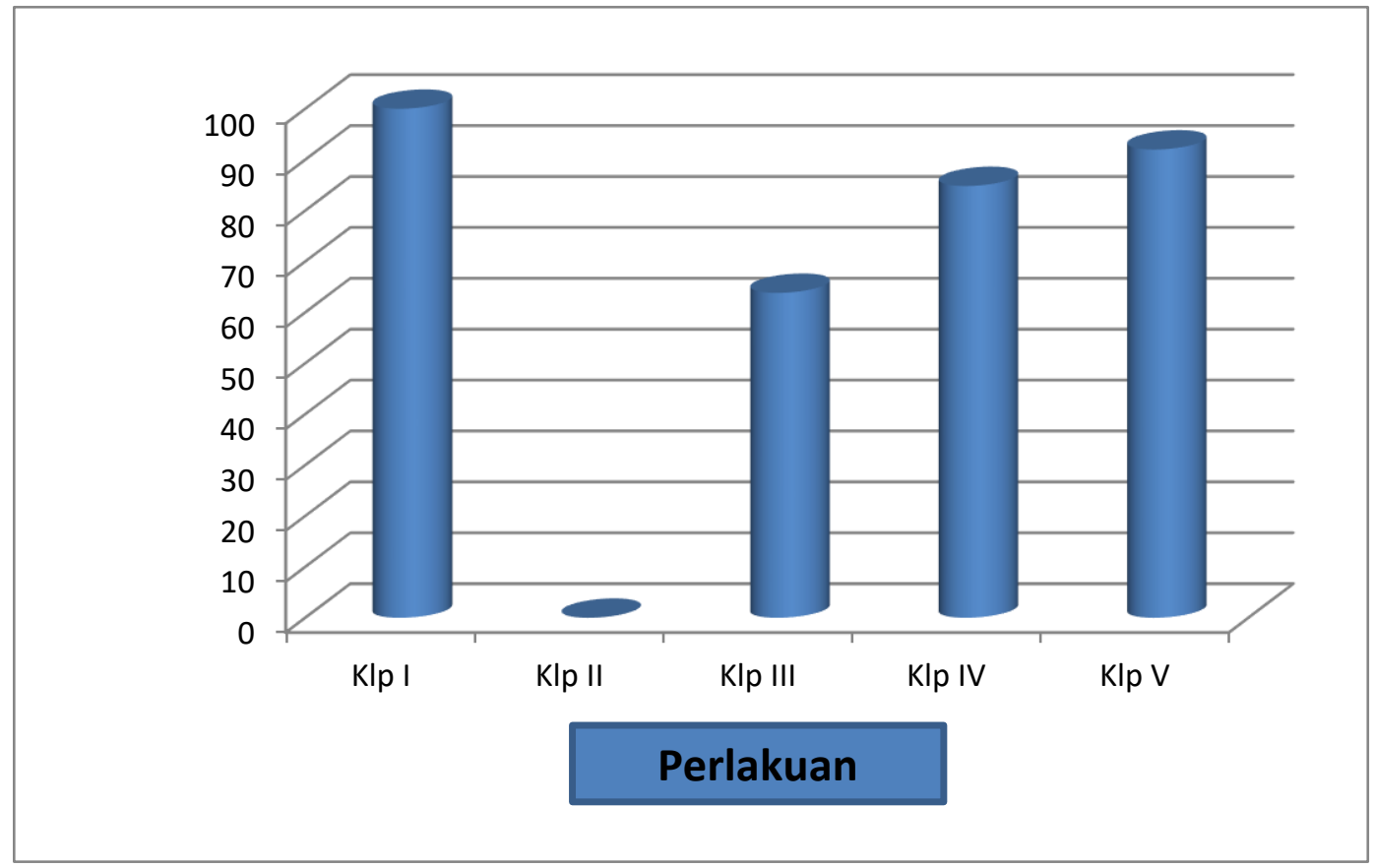


Pengamatan mikronukleus pada mikroskop
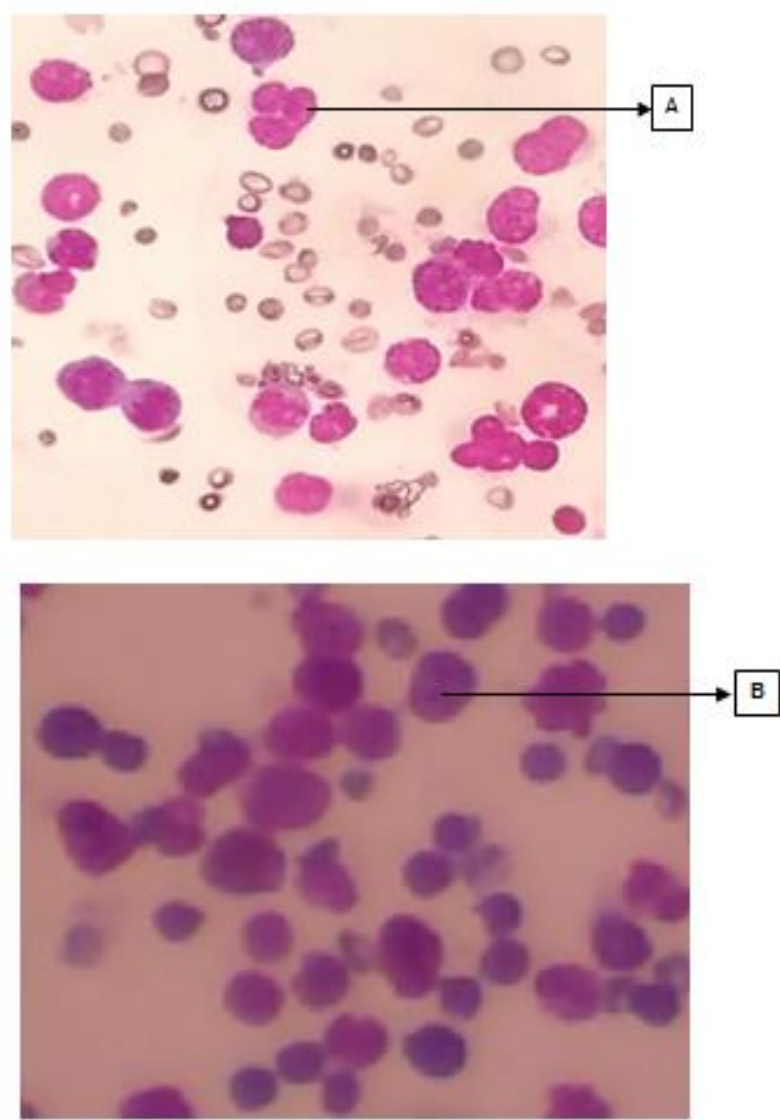

Gambar 17. Pengamatan kelompok Ekstrak daun keladi tikus 1,5 $\mathrm{mg} / \mathrm{kgBB}$ (perbesaran $1000 \mathrm{x}+5 \mathrm{x}$ optical zoom)

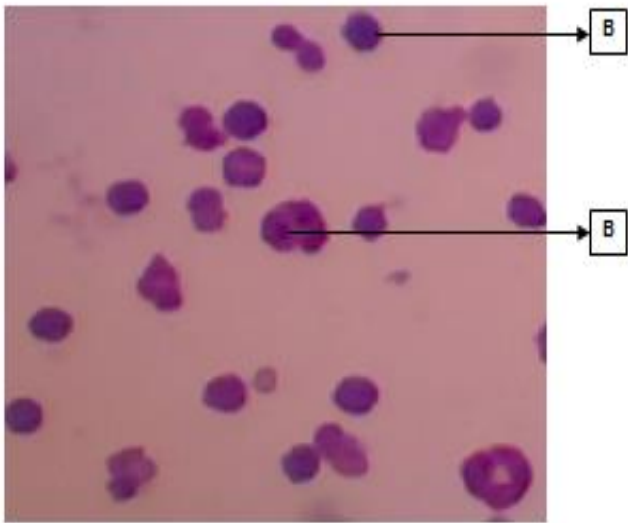

Gambar, 15, Pengamatan kelompok ekstrak daun keladi tikus 0,5 $\mathrm{mg} / \mathrm{kgBB}$ (perbesaran $1000 \mathrm{x}+5 \mathrm{x}$ optical $200 \mathrm{~m}$ )

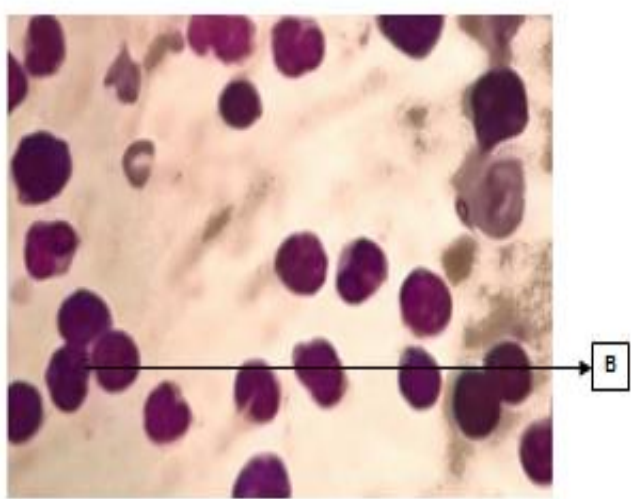

Gambar 16. Pengamatan kelompok Ekstrakdaun keladi tikus $1 \mathrm{mg} / \mathrm{kgBB}$ (perbesaran $1000 x+5 x$ optical $200 m$ ) 